\title{
Hodnocení materiálů používaných při readjustaci a ukládání daguerrotypií pomocí modifikovaného Oddyho testu
}

\section{Evaluation of materials for recasing and preservation of daguerreotypes using modified Oddy test}

\author{
Švadlena J. ${ }^{1}, 2$, Borýsková $\check{S} .^{2}$ \\ ${ }^{1}$ Ústav kovových materiálů a korozního inženýrství, VŠCHT Praha \\ ${ }^{2}$ Kabinet restaurování fotografie FAMU \\ E-mail: jan.svadlena@vscht.cz
}

Významným nebezpečím pro dlouhodobé zachováni historických kovových predmětu jsou nevhodné podminky uloženi a použití materiálù, které mohou být zdrojem polutantů ve vnitřnich atmosférách. Materiály navržené pro použití při ochraně a uloženi sbirkových předmètů je potřeba dostatečně ověrit z hlediska bezpečnosti pro chránèné předměty, než mohou být tyto materiály s jistotou doporučeny. Jednou ze základnich technik použivaných pro účely testováni nových i ověreni již použivaných materiálů je tzv. Oddyho test, jehož výhody spočivaji $v$ jeho jednoduchosti na experimentální vybavení a možnosti modifikovat tuto metodu pro konkrétni použití. V této práci je uplatněna varianta Oddyho testu modifikovaná pro konkrétni prripad - hodnoceni materiálü, které se použivaji při readjustaci daguerrotypii. Vedle běžně použivaného vizuálního hodnoceni výsledkủ Oddyho testu byla pro porovnání použita i elektrochemická redukce korozních produktů na exponovaných vzorcích. Výsledky naznačuji, že vliv testovaných materiálů je minoritni v porovnánís vlivem stavu povrchu daguerrotypie. Tento závěr odpovidá předpokladìm bezpečnosti testovaných materiálů, které se v konzervátorské praxi použivaji při ochraně archivních a historických fotografických fondü.

\section{ÚVOD}

Pojem daguerrotypie označuje jak historickou fotografickou metodu, tak výsledné snímky touto metodou vytvořené. Jedná se o jeden z nejstarších fotografických postupů, který se výrazně lišil od pozdějších fotografických technik - obraz je tvořen částicemi amalgámu stř́bra na postříbřené měděné desce a jedná se o kombinaci pozitivního a negativního obraz zároveň, v závislosti na úhlu pozorování, což s sebou nese skutečnost, že daguerrotypický snímek nelze klasickými fotografickými postupy (získání více pozitivních snímků z jednoho negativu) kopírovat a každá daguerrotypická deska je jedinečná. O to větší nebezpečí pro daguerrotypie představují různé degradační pochody ohrožující obrazovou vrstvu. Součástí daguerrotypie také bývá historická
Unsuitable storage conditions and use of materials which may be a source of pollutants in indoor environments are major threats to the long-term preservation of historic metal objects. Materials proposed for use in protecting and storage of museum or archive collections need to be sufficiently verified in terms of safety for the protected objects before these materials can be safely recommended. One of the basic techniques used for the purpose of testing of new materials (and verifying of those that are already in use) is the Oddy test whose advantages lies in its simple requirements for the experimental equipment and a possibility to modify this method for a particular use. In this work, a variant of the Oddy test was applied with a modification for a specific case - evaluation of materials used for recasing of daguerreotypes. Besides the commonly used visual assessment, electrochemical reduction of corrosion products on the exposed samples was used to compare the Oddy test results. The results indicate that the influence of the test materials is minor compared to the influence of the state of the daguerreotypes surface. This conclusion is consistent with expectations about safety of the tested materials that are used in conservation practice for the protection of archival and historical photographic collections.

adjustace, která podle typu může obsahovat papírové a kovové (nejčastěji mosazné) pasparty a rámečky, krycí sklo a vnější ozdobnou schránku ze dřeva nebo termoplastu $[1,2]$.

Mezi degradační faktory, kterým bývají daguerrotypie nejčastěji vystaveny, patř́i mechanické poškození (plyne z nízké mechanické odolnosti a otěruvzdornosti obrazové vrstvy), nevhodné čistící a konzervační zásahy, poškození a degradace adjustace (například koroze krycího skla vedoucí k tvorbě alkalického roztoku na povrchu), nevyhovující podmínky uložení a polutanty stimulující korozní poškození $[1,2]$. Z hlediska korozního poškození se $\mathrm{v}$ případě daguerrotypií jedná především a korozi stříbra, případně podkladové mědi. Analytickými metodami byla na povrchu historických daguerrotypií prokázána přítomnost korozních produktů na bázi oxidů, 
sulfidů a chloridů stříbra a mědi $\left(\mathrm{AgCl}, \mathrm{Ag}_{2} \mathrm{O}, \mathrm{Ag}_{2} \mathrm{~S}\right)$, př́ípadně kyanidu stř́ibrného AgCN (daguerrotypie čištěná nevhodným postupem v kyanidové lázni) [2-4].

Pro zpomalení degradace historických předmětů při dlouhodobém uložení a zajištění jejich stability je vedle zvolení vhodného a bezpečného restaurátorského postupu a adekvátních konzervačních zásahů nutné věnovat pozornost také podmínkám uložení a vlastnostem materiálů $\mathrm{k}$ tomuto účelu sloužícím. Ideálním předpokladem pro dlouhodobé uložení historického předmětu je prostředí bez polutantů. Nejčastějším zdrojem plynných polutantů (například sloučeniny síry, organické kyseliny, formaldehyd aj.) ve vnitřních atmosférách bývají nevhodné materiály použité např́iklad v konstrukci depozitářů, vitrín a výstavních prostor nebo v obalových prostředcích a adjustacích. Proto je důležité a nutné ověřit vhodnost materiálů navržených pro takové ochranné účely $[5,6]$. $\mathrm{V}$ případě konzervace a uložení daguerrotypií se také hodnotí stav a poškození původní adjustace. Pokud je původní adjustace silně poškozena nebo není zachována vůbec, často se volí readjustace daguerrotypické desky za použití současných materiálů $[1,2]$.

Základní, jednoduchou a přitom spolehlivou metodou pro ověření vhodnosti použití materiálů pro ochranu a uložení historických předmětů je tzv. Oddyho test (1973, The British Museum). Test využívá strúbro, měd' a olovo, což jsou kovy velmi citlivé na polutanty ohrožující historické předměty ve vnitřních atmosférách, jako jsou sulfan a sloučeniny síry obecně (stříbro, měd'), organické kyseliny a aldehydy (olovo) nebo sloučeniny obsahující chlór (měd'). Základní uspořádání Oddyho testu představuje neprodyšně uzavřená nádoba obsahující kovové kupóny, testovaný materiál a demineralizovanou vodu zajišt'ující prostředí $100 \%$ relativní vlhkost. Celé toto uspořádání je zahříváno na $60{ }^{\circ} \mathrm{C}$ po dobu 4 týdnů. Pro vyhodnocení je používáno především vizuální hodnocení stavu kovových kupónu po expozici $[7,8]$.

Během použivání Oddyho testu bylo vyvinuto a uvedeno do praxe množství modifikací, např. pro zlepšení reprodukovatelnosti nebo zkrácení doby testování. Úpravy postupu se týkaly množství použité vody, velikosti, tloušt'ky a umístění kovových kupónů, případně použití méně standardních kupónů pro speciální použití (tenké deponované stř́brné vrstvy apod.) [9-11]. Zajímavou variantu pro hodnocení materiálů pro readjustace daguerrotypií nabízí použití kovového kupónu připraveného historickým daguerrotypickým procesem, který umožňuje hodnotit dopad testovaných materiálů přímo na daguerrotypie [11]. Tento př́stup byl zvolen i v této práci.

Bez ohledu na různé modifikace zůstává samotný princip Oddyho testu nadále stejný - jeho spolehlivost mj. prokázalo dlouhodobé užívání tohoto testu jak v samotném The British Museum tak i např. v J. Paul Getty Museum Los Angeles nebo v The Metropolitan Museum of Art New York [9, 12].

\section{EXPERIMENTÁLNÍ ČÁST}

Pro testování vhodnosti pro účely readjustace a uložení daguerrotypií pomocí upraveného Oddyho testu byly místo stříbrných, měděných a olověných kupónů použité daguerrotypické vzorky připravené dle historického postupu.

\section{Příprava daguerrotypických vzorků}

Základem daguerrotypických vzorků byly galvanicky postř́břené (Tab. 1, tloušt'ka stř́ibrné vrstvy činila přibližně $2 \mu \mathrm{m}$ ) měděné destičky o rozměrech $50 \times 15 \mathrm{~mm}$. Stříbrný povrch těchto vzorkủ byl leštěn $\mathrm{v}$ několika krocích pro dosažení požadovaného zrcadlového lesku - nejprve byl každý vzorek leštěn na rotační zlatnické leštičce pomocí flanelového kotouče a leštící pasty (leštící pasta pro barevné kovy, na bázi $\mathrm{Al}_{2} \mathrm{O}_{3}$ a $\mathrm{Fe}_{2} \mathrm{O}_{3}$ ), následovalo důkladné očistění povrchu vzorku od zbytků leštící pasty vatou s etanolem a pro finální doleštění byl použit mušelínový kotouč $\mathrm{s}$ velmi jemným práškovým $\mathrm{Fe}_{2} \mathrm{O}_{3}$ a nakonec byl vyleštěný stříbrný povrch vzorků jemně očištěn suchou vatou (pro odstranění zbytků abraziva a případného prachu). V souladu s historickým daguerrotypickým postupem byly vzorky zcitlivovány v parách jódu po dobu $80 \mathrm{~s}$ do požadovaného stupně zcitlivění (kontrolováno pomocí změn barevnosti povrchu během zcitlivění). Pro expozici byl použit analogový fotoaparát na svitkový film (Flexaret Standard), doba expozice činila 8,5 min při cloně 5,6. Vzorky byly ve fotoaparátu uchyceny pomocí oboustranné lepicí pásky, jejíž zbytky byly po ustalování důkladně odstraněny etanolem. Vyvolávání obrazu probíhalo $\mathrm{v}$ parách rtuti po dobu 3 minut (skleněný exsikátor se rtutí zahříván

Tab. 1. Postup stř́bření vzorků pro daguerrotypický proces / Silvering of the samples for the daguerreotype process

\begin{tabular}{|l|c|c|c|}
\hline & Složení lázně & Čas [s] & $\begin{array}{c}\text { Proudová hustota } \\
{\left[\mathbf{A} \mathbf{d m}^{-2}\right]}\end{array}$ \\
\hline 1. Aktivace & KCN o koncentraci $10 \mathrm{~g} \mathrm{l}^{-1}$ & 30 & - \\
\hline 2. Předstříbření & Kyanidová stříbřící lázeň s obsahem stř́bra 2-3 $\mathrm{g} \mathrm{l}^{-1}$ & 60 & $1-1,5$ \\
\hline 3. Stř́bření & $\begin{array}{c}\text { Kyanidová stříbř́í lázeň s obsahem stř́bra 30-40 } \mathrm{g} \mathrm{l}^{-1} \\
+ \text { přídavek } \mathrm{K}_{2} \mathrm{CO}_{3} \text { na zvýšení vodivosti }\end{array}$ & 180 & 1 \\
\hline
\end{tabular}


na $90{ }^{\circ} \mathrm{C}$ ). Po vyvolání byly vzorky „ustáleny“ (odstranění nezreagovaných halogenidů stř́ibra) v 5\% roztoku $\mathrm{Na}_{2} \mathrm{~S}_{2} \mathrm{O}_{3} \mathrm{~s}$ následným opláchnutím destilovanou vodou a sušením. Vzorky (Obr. 1, 2) nebyly zlaceny.

Uvedeným postupem byly připraveny dvě série vzorků. První série vzorků byla po zhotovení daguerrotypickým procesem ponechána 4 týdny v laboratorních podmínkách (předexponování) a poté umístěna do pod-

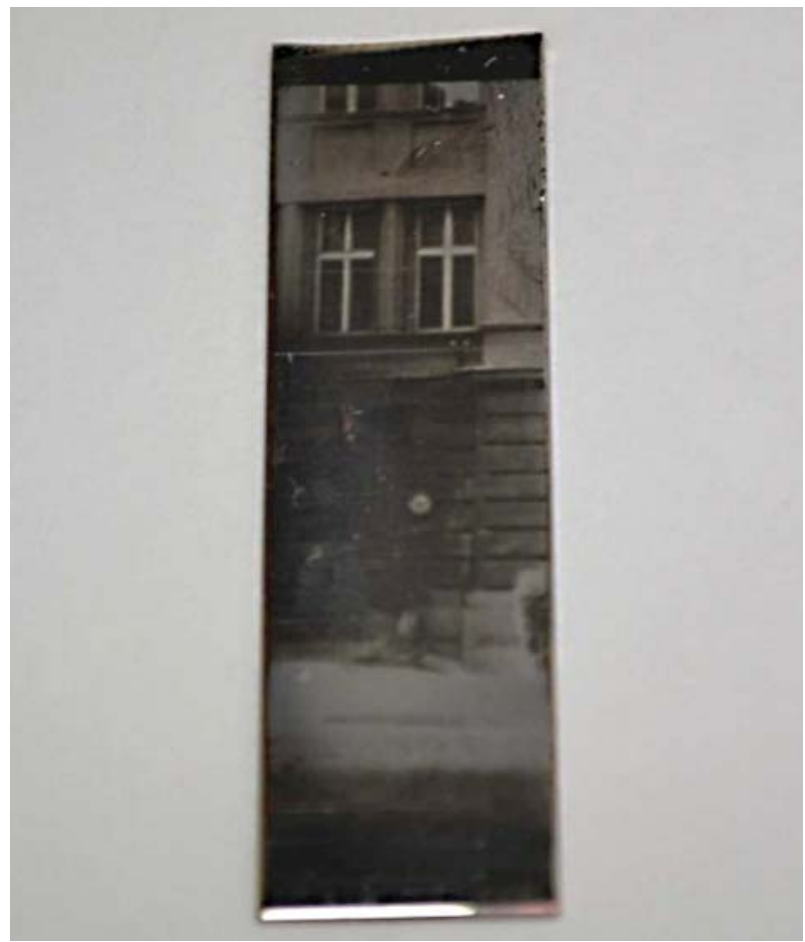

Obr. 1. Daguerrotypický vzorek (pozitivní obraz)

Fig. 1. Daguerreotype sample (positive image) mínek Oddyho testu, druhá série vzorků byla vystavena podmínkám Oddyho testu ihned po zhotovení.

\section{Testované materiály}

Dle uživané praxe restaurování a konzervační readjustace fotografických materiálů byly pro testování zvoleny následující materiály (Tab. 2):

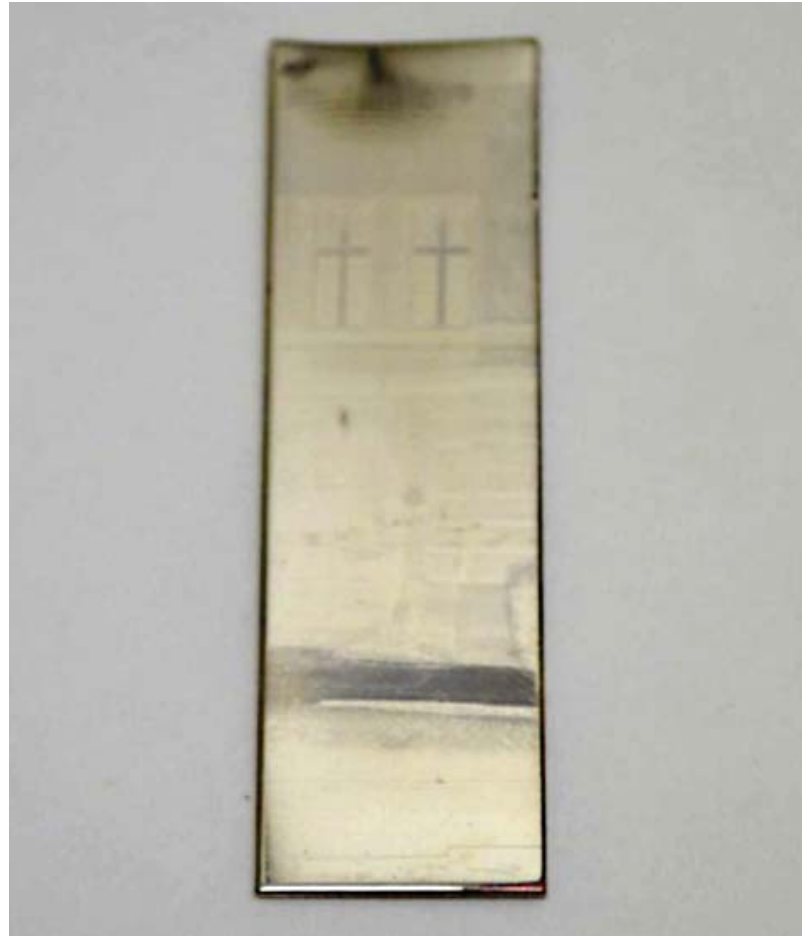

Obr. 2. Daguerrotypický vzorek (negativní obraz)

Fig. 2. Daguerreotype sample (negative image)

Tab. 2. Testované materiály / Tested materials

\begin{tabular}{|c|c|c|c|}
\hline Obchodní název & Chemické složení/specifikace & Dodavatel/výrobce & Použití \\
\hline $\begin{array}{l}\text { Gummed Linen } \\
\text { Hinging tape }\end{array}$ & $\begin{array}{l}\text { lepicí páska z bílé lněné tkaniny s pH } \\
\text { neutrálním lepidlem se silnou přilna- } \\
\text { vostí; lepidlo se aktivuje navlhčením; } \\
\text { archivní kvalita }\end{array}$ & $\begin{array}{l}\text { Lineco, University } \\
\text { Products Inc. }\end{array}$ & $\begin{array}{l}\text { pro uchycení uměleckých děl a tisků } \\
\text { s větší hmotností do paspart a rámů }\end{array}$ \\
\hline $\begin{array}{l}\text { Self-adhesive Frame } \\
\text { Sealing tape (white) }\end{array}$ & $\begin{array}{c}\text { samolepicí hliníková páska } \\
\text { s permanentním nevysychavým } \\
\text { akrylátovým lepidlem, archivní kvalita }\end{array}$ & $\begin{array}{l}\text { Lineco, University } \\
\text { Products Inc. }\end{array}$ & $\begin{array}{l}\text { pro vytvoření bariéry } \\
\text { od nevhodných obalových materiálů, } \\
\text { např̀. dřevěných rámů }\end{array}$ \\
\hline $\begin{array}{l}\text { Papír na obálky } \\
\text { (pro čtyřchlopňové } \\
\text { obálky, skládané obálky } \\
\text { a volné listy): }\end{array}$ & $\begin{array}{c}\text { bavlněný papír s gramáží } 90 \mathrm{~g} / \mathrm{m}^{2} \text {; } \\
\text { bez optických zjasňovačú; } \mathrm{pH} \text { neutrální; } \\
\text { odpovídá normě PAT test } \\
\text { dle ANSI IT9.16 }\end{array}$ & Emba spol. s r.o. & $\begin{array}{c}\text { pro ukládání } \\
\text { fotografických materiálů } \\
\text { pro dlouhodobou archivaci }\end{array}$ \\
\hline $\begin{array}{l}\text { Plastazote LD45 } \\
\text { (bílá, černá barva) }\end{array}$ & $\begin{array}{l}\text { polyethylenová nestlačitelná nízkohus- } \\
\text { totní pěna; nízká hmotnost s velkou } \\
\text { pevností; chemicky odolná, netoxická, } \\
\text { bez zápachu a neabsorbuje vodu }\end{array}$ & Zotefoams & $\begin{array}{l}\text { pro ukládání různých archiválií } \\
\text { při potřebě uložení specifických } \\
\text { tvarů nebo křehkého předmětu; } \\
\text { vhodné pro dlouhodobou archivaci }\end{array}$ \\
\hline
\end{tabular}


Tab. 2. Testované materiály / Tested materials

\begin{tabular}{|c|c|c|c|}
\hline Obchodní název & Chemické složení/specifikace & Dodavatel/výrobce & Použití \\
\hline $\begin{array}{l}\text { Archivní lepenka } \\
\text { Prolux } 1 \text { (pro archivní } \\
\text { program Fotoarchiv) }\end{array}$ & $\begin{array}{c}\text { pH 8,0-9,5; tloušt'ka } 1 \text { mm; odpovídá } \\
\text { normě ANSI/NISO Z39.48: } 1992 \text { a PAT } \\
\text { testu dle ANSI IT9.16 }\end{array}$ & Emba spol. s r.o. & $\begin{array}{l}\text { pro ukládání obalených } \\
\text { fotografických materiálů } \\
\text { pro dlouhodobou archivaci }\end{array}$ \\
\hline $\begin{array}{l}\text { Fomapan } 100 \text { listový } \\
\text { (různé formáty) }\end{array}$ & $\begin{array}{l}\text { černobílý negativní plochý film } \\
\text { s citlivostí } 100 \mathrm{ASA} / 21^{\circ} \mathrm{DIN}, 100 \% \\
\text { polyethylentereftalátová podložka }\end{array}$ & $\begin{array}{l}\text { Foma Bohemia } \\
\text { spol. s r.o. }\end{array}$ & $\begin{array}{l}\text { V restaurátorské praxi užívaný } \\
\text { jako stabilní čirá nebo černá krycí } \\
\text { nebo podkladová folie }\end{array}$ \\
\hline Archivační papír & $\begin{array}{c}\text { papír s obsahem } 50 \% \text { bavlny a } 50 \text { \% } \\
\text { čisté celulózy; gramáž do } 120 \mathrm{~g} / \mathrm{m}^{2} \text {, } \\
\text { dle normy ISO } 9706\end{array}$ & DYTEC s.r.o., & $\begin{array}{c}\text { v restaurátorské praxi užívaný } \\
\text { jako výlepový, obalový a doplňující } \\
\text { papír; vhodné pro dlouhodobou } \\
\text { archivaci }\end{array}$ \\
\hline Melinex 401 & $\begin{array}{l}\text { čirá } 100 \% \text { polyetylentereftalátová fólie; } \\
\text { vysoce transparentní, inertní a chemicky } \\
\text { i rozměrově stabilní a nežloutne }\end{array}$ & $\begin{array}{l}\text { DuPont Teijin } \\
\text { Films }\end{array}$ & $\begin{array}{l}\text { pro dlouhodobou ochranu } \\
\text { archivních dokumentů, tisků, knih a } \\
\text { listin v depozitářích nebo } \\
\text { při vystavování; velmi dobře ochrání } \\
\text { před prachem, špínou, otisky prstů } \\
\text { a jiným znečištěním. }\end{array}$ \\
\hline $\begin{array}{l}\text { Archivní krabice } \\
\text { Fotoarchiv }\end{array}$ & $\begin{array}{c}\text { nelepená skládaná krabice s archivní } \\
\text { lepenky Prolux } 1 \text { nebo Extracel; } \\
\text { pH 8,0-9,5; odpovídá normě ANSI/ } \\
\text { NISO Z39.48: } 1992 \text { a PAT testu } \\
\text { dle ANSI IT9.16 }\end{array}$ & Emba spol. s r.o. & $\begin{array}{l}\text { pro ukládání } \\
\text { obalených fotografických materiálů } \\
\text { pro dlouhodobou archivaci }\end{array}$ \\
\hline $\begin{array}{l}\text { Marvelseal } 360-470 \\
\text { (Melinex fólie s Al } \\
\text { vrstvou }\end{array}$ & $\begin{array}{l}\text { vrstvená hliníková folie s polyetyleno- } \\
\text { vou a polypropylenovou vrstvou }\end{array}$ & různí dodavatelé & $\begin{array}{l}\text { pro vytvoření bariéry } \\
\text { od nevhodných obalových materiálů } \\
\text { a ochranu před působením } \\
\text { agresivních oxidačně redukčních } \\
\text { činidel z vnějšího prostředí, } \\
\text { vhodné pro dlouhodobou archivaci }\end{array}$ \\
\hline
\end{tabular}

\section{Uspořádání Oddyho testu}

Na základě předběžných zkušebních měření bylo pro Oddyho test zvoleno následující uspořádání:

- Do skleněné uzavíratelné nádoby (objem 130 ml) s polypropylenovým víčkem (Obr. 3) byly odměřeny $2 \mathrm{ml}$ demineralizované vody.

- Do téže nádoby byla umístěna skleněná laboratorní kádinka (objem 25 ml, Obr. 3).

- Na dno kádinky byl vložen jeden z uvedených testovaných materiálů (vzorek materiálu velikosti přibližně $10 \times 20 \mathrm{~mm}$, Obr. 4).

- Do kádinky s testovaným materiálem byl umístěn připravený daguerrotypický vzorek tak, aby se nedotýkal testovaného materiálu (Obr. 4, 5). Výjimku tvořily vzorky adhesivních pásek (Gummed linen hinging tape a Self-adhesive Frame Sealing tape (white)), které byly prrichyceny ze zadní strany daguerrotypického vzorku.
- Skleněné nádoby se vzorky byly důkladně uzavřeny a umístěny do sušárny s teplotou $60{ }^{\circ} \mathrm{C}$. Zhruba po 30 minutách bylo zkontrolováno uzavření skleněných nádob, a pokud bylo potřeba, bylo polypropylenové víčko dotaženo nebo utěsněno izolační páskou.

- V těchto podmínkách byly vzorky ponechány po dobu 4 týdnů.

Do obou sérií vzorků byl přidán i slepý vzorek, který je umístěn v podmínkách Oddyho testu samostatně, bez žádného z testovaných materiálů. Slouží pro odlišení vlastní degradace daguerrotypického vzorku v těchto podmínkách $\left(60^{\circ} \mathrm{C}, 100 \% \mathrm{RH}\right)$ od poškození způsobeného př́tomností testovaného materiálu.

\section{Vyhodnocení}

Vedle vizuálního hodnocení, které může být značně subjektivní, byla míra poškození vzorků ověřována metodou elektrochemické redukce korozních produktů, pomocí které je možné porovnat tloušt'ku vrstvy korozních produktů jednotlivých vzorků. Redukce probíhala 
$\mathrm{v}$ roztoku $\mathrm{KCl} \mathrm{s}$ koncentrací $0,1 \mathrm{~mol} \mathrm{dm}^{-3}$, který byl před každým měřením zbaven kyslíku probubláváním dusíkem (po dobu 1 hodiny). Pro redukci byla zvolena proudová hustota $-1,2 \mathrm{~A} \mathrm{~m}^{-2}$. Korozní poškození jednotlivých vzorků bylo porovnáváno se slepým vzorkem. Pro ověření složení korozních produktů byl povrch analyzován v elektronovém mikroskopu pomocí prvkové EDS analýzy.

\section{VÝSLEDKY}

Korozní poškození všech vzorků bylo nerovnoměrné, lokalizované zejména $\mathrm{v}$ místech povrchových poruch $($ Obr. 6,7$)$ - např́klad ve zbylých rýhách po leš- tění. První série vzorků, která byla před expozicí ponechána 4 týdny v laboratorních podmínkách (předexpozice), vykazovala ve většině případů vyšší míru poškození $($ Obr. 8, 9) oproti vzorkům bez předexpozice. Příčinou může být depozice prachu na vzorcích vystavených v takto nechráněném prostředí a přirozený vznik kompaktní vrstvy korozních produktů (oxidů). I slabé znečištění a korozní poškození tedy stimuluje další degradaci daguerrotypií.

Relativní rozdíly mezi jednotlivými vzorky (v porovnání se slepým vzorkem) po expozici, plynoucí jak z výsledků redukce korozních produktů, tak vizuálního hodnocení, nesouhlasí při porovnání první (předexponované) a druhé (čistý povrch) série vzorků (Obr. 10). Zároveň také výsledky obou způsobů hodnocení

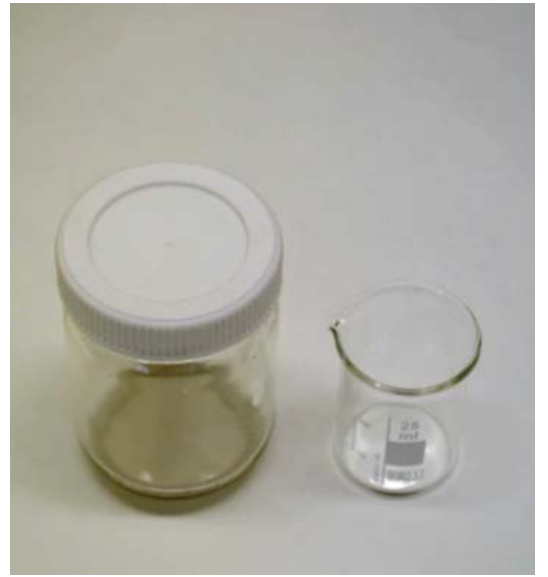

Obr. 3. Nádoba s $25 \mathrm{ml}$ kádinkou Fig. 3. Container with $25 \mathrm{~mL}$ beaker

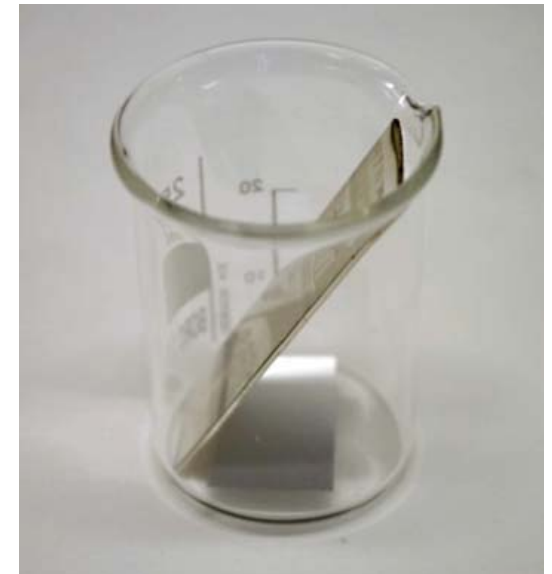

Obr. 4. Umístění vzorku

Fig. 4. Placement of the daguerreotype sample

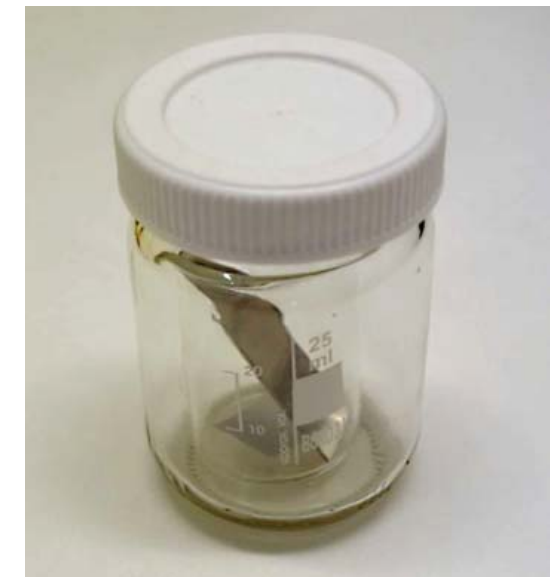

Obr. 5. Nádoba se vzorkem a testovaným materiálem připravená $\mathrm{k}$ umístění do sušárny

Fig. 5. Container with the sample and tested material ready to be placed in the heating chamber

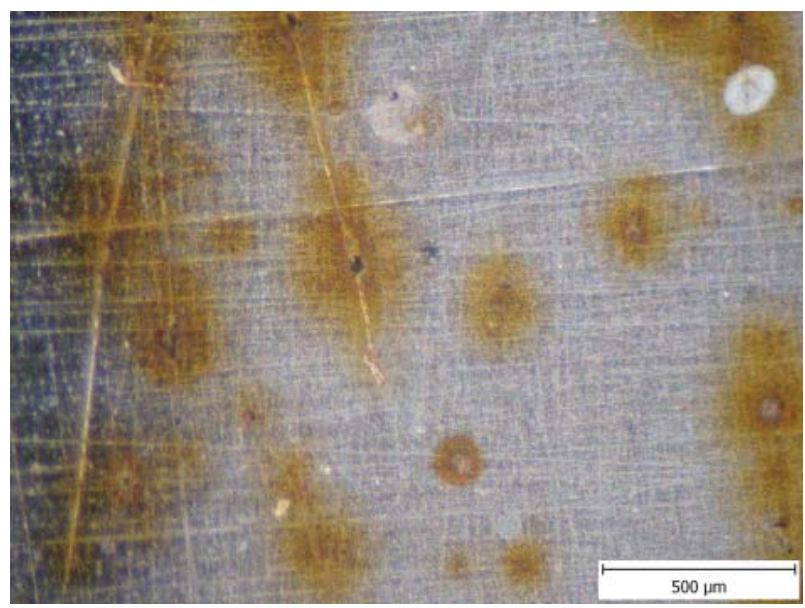

Obr. 6. Povrch exponovaného vzorku s lokalizovaným korozním poškozením

Fig. 6. Surface of the exposed sample with localised corrosion damage

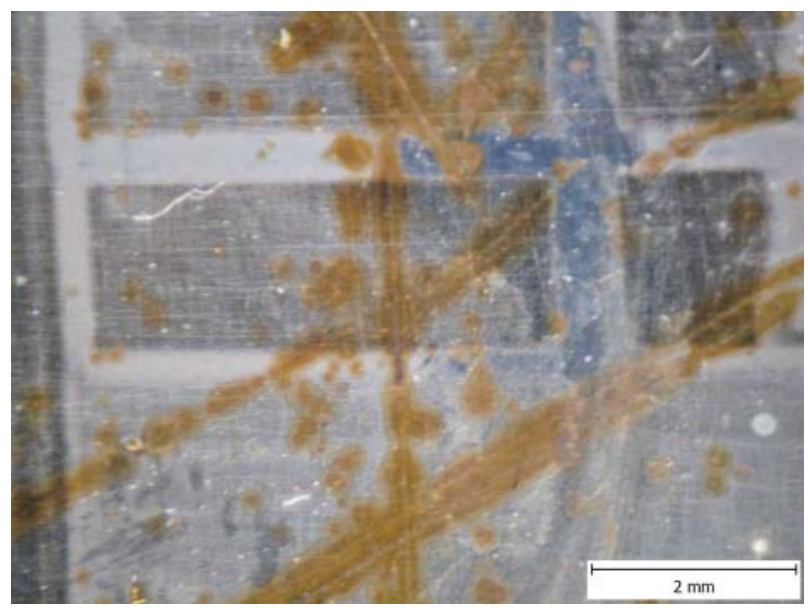

Obr. 7. Povrch exponovaného vzorku s lokalizovaným korozním poškozením

Fig. 7. Surface of the exposed sample with localised corrosion damage 


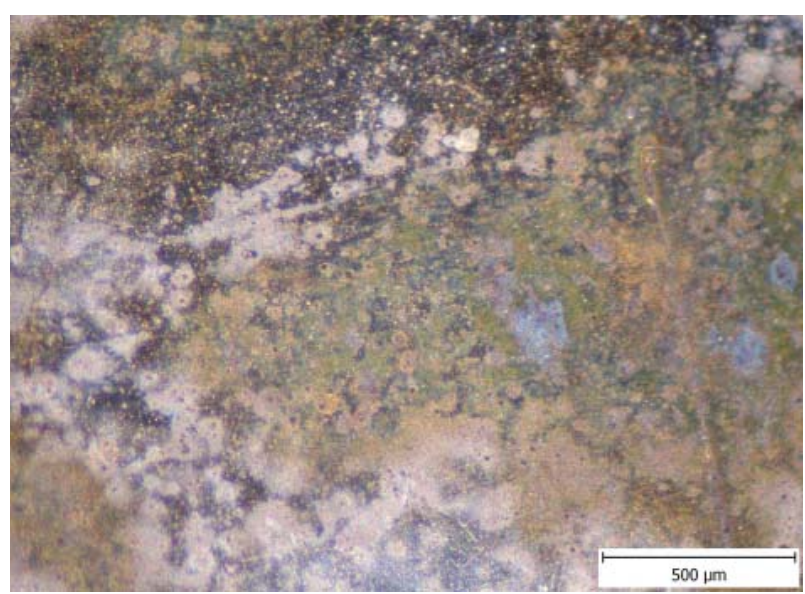

Obr. 8. Předexponovaný vzorek s větší intenzitou korozního poškození

Fig. 8. Pre-exposed sample with greater intensity of corrosion damage

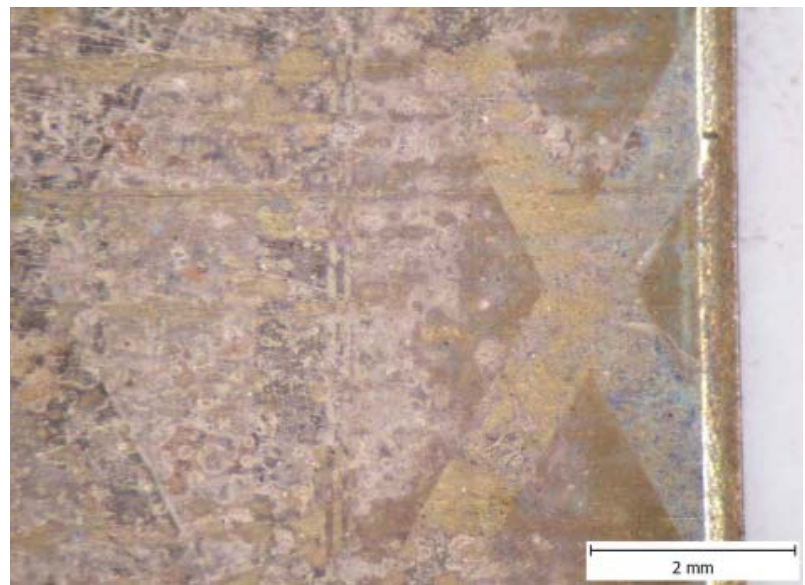

Obr. 9. Okraj vzorku s kompaktnějším korozním poškozením

Fig. 9. Edge of the sample with compact corrosion damage

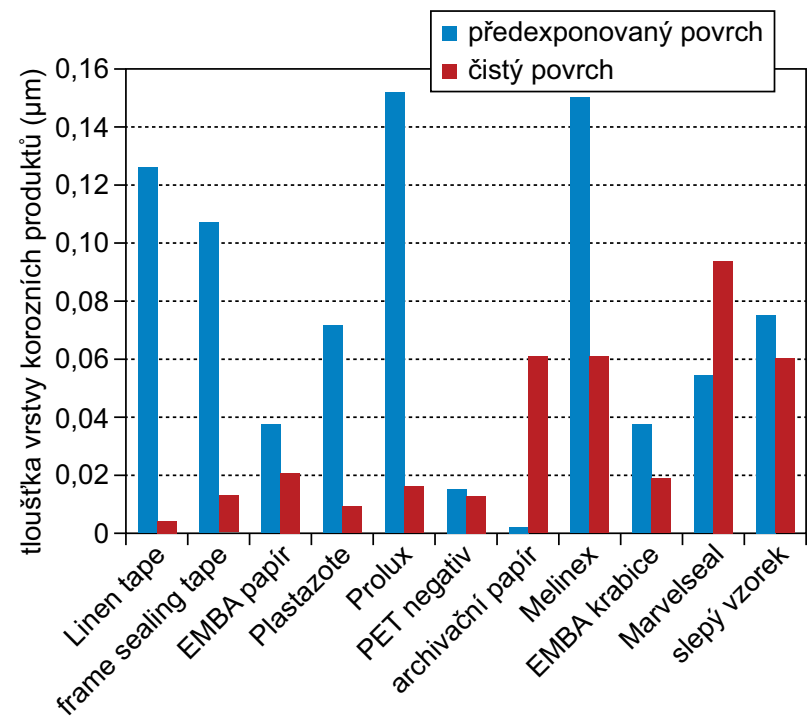

Obr. 10. Porovnání tlouštky vrstvy korozních produktů

Fig. 10. Comparison of thickness of the corrosion products (vizuální hodnocení a zjištění tloušt'ky vrstvy korozních produktů redukcí) sobě neodpovídají, vzorky s delšími redukčními časy (odpovídá větší tloušt'ce vrstvy korozních produktů) nemusí na pohled vykazovat větší míru poškození (jako tomu bylo například u vzorku s fólií Melinex 401). Je to způsobeno právě nerovnoměrností a lokálním charakterem poškození, kdy může docházet $\mathrm{k}$ intenzivnímu koroznímu poškození $\mathrm{v}$ povrchových poruchách.

Intenzivnější poškození lze sledovat u vzorků s adhesivními páskami v místě kontaktu a v blízkém okolí (Obr. 9). V první sérii bylo výraznější poškození pozorováno $\mathrm{u}$ vzorku exponovaného $\mathrm{s}$ polyethylenovou pěnou plastazote, ve druhé sérii stejný materiál výrazné poškození nezpůsobil. Obdobně na tom byl vzorek exponovaný s průhlednou melinexovou fólií, který byl v první sérii vzorků bez výraznějšího poškození a ve druhé byl jeho vzhled vrstvou korozních produktů ovlivněn nejvíce.

Lokalizovaný charakter poškození neměl dle pozorování v rastrovacím elektronovém mikroskopu (Obr. 11) vliv na částice amalgámu stříbra. Z EDS analýzy korozních produktů vyplývalo, že jsou tvořeny převážně oxidy.

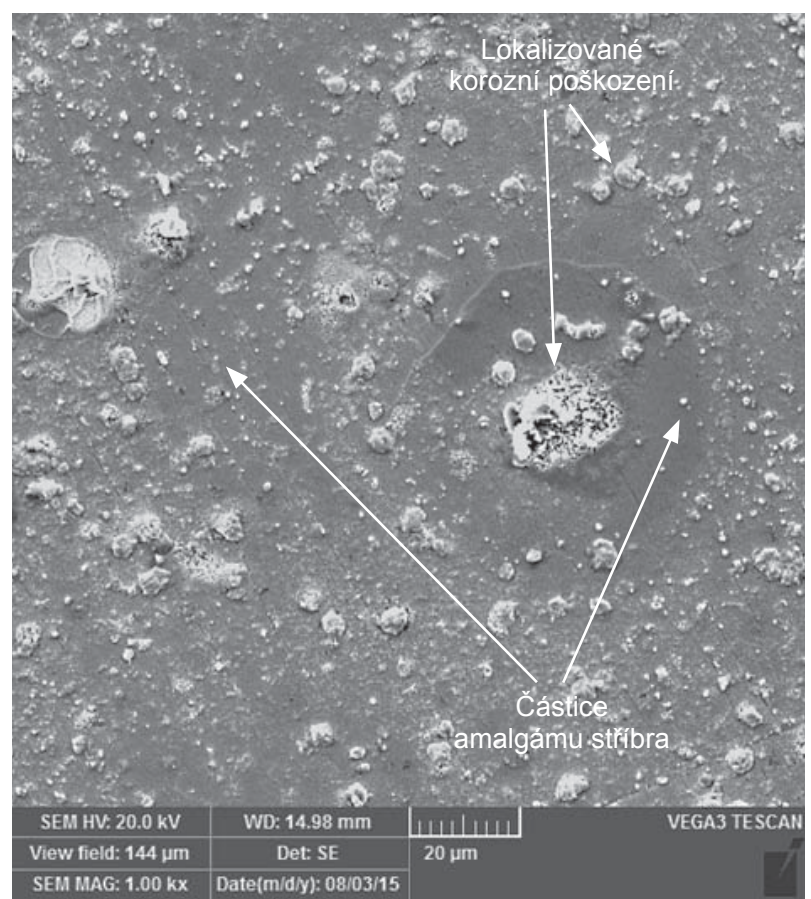

Obr. 11. Povrch vzorku po expozici s lokálním korozním poškozením

Fig. 11. Surface of the sample with localized corrosion damage after the exposure 


\section{ZÁVĚR}

Na základě uvedených výsledků vyplývá, že stav povrchu daguerrotypií je mnohem výraznější faktor, než vliv testovaných materiálů. Uvedené materiály jsou rozšířené $\mathrm{v}$ restaurátorské praxi, jejich bezpečnost byla už v konkrétních praktických aplikacích ověřena a lze je použít na readjustaci historických daguerrotypií. Zvýšenou pozornost je třeba dbát při použití adhesivních pásek, jejichž kontakt s daguerrotypickou deskou může negativně ovlivnit její korozní odolnost a způsobit vyšší míru degradace. Obsah testu tak mimo jiné fakticky potvrzuje nutnost maximálně individuálního přístupu ke každé konkrétní daguerrotypii, kde mnohá poškození jsou př́mým důsledkem vlastního technologického daguerrotypického postupu.

\section{Poděkování}

Tato studie vznikla na Akademii múzických umění v Praze v rámci projektu NAKI DF12P01OVV038 - „Daguerrovo rejsování svétlem“ - nové metody a postupy pro ochranu, péči a zpř́stupnéni kulturního dědictví v daguerrotypii (2012-2015, MKO/DF) - finančně podpořeného z prostředkü $M K \check{C} R$ v roce 2014.

\section{LITERATURA}

1. Barger, S.; White, W. B., The Daguerreotype: NineteenthCentury Technology and Modern Science. Johns Hopkins University Press: 2000.
2. Švadlena, J. Daguerrotypie - první prakticky používaná fotografická technika. Koroze a ochrana materiálu 2014, $58(2), 59-64$.

3. Centeno, S. A.; Meller, T.; Kennedy, N.; Wypyski, M. The daguerreotype surface as a SERS substrate: characterization of image deterioration in plates from the $19^{\text {th }}$ century studio of Southworth \& Hawes. J. Raman Spectrosc. 2008, 39, 914-921.

4. Marquis, E. A.; Chen, Y.; Kohanek, J.; Dong, Y.; Centeno, S. A. Exposing the sub-surface of historical daguerreotypes and the effects of sulfur-induced corrosion. Corros. Sci. 2015, 94, 438-444.

5. Tétreault, Jean. Airborne Pollutants in Museums, Galleries, and Archives: Risk Assessment, Control Strategies, and Preservation Management. Ottawa: Canadian Conservation Institute; 2003; ISBN: 0-662-34059-0.

6. Kolektiv: Preventivní ochrana sbírkových předmětů. Národní muzeum Praha, 2001.

7. Oddy, W. A. An unsuspected danger in display. Museum Journal, 1973, 73, 27-28

8. Berger, I.; Kulhavá, B.; Šimčík, A.; Vrajová, J.; Hložek, M. Oddyho test, seznámení s tradiční metodou a získanými výsledky. In Sborník $z$ konference konzervátorů a restaurátorů. 1. vyd. Brno: Technické muzeum v Brně, 2007. s. 7-11.

9. Bamberger, J. A.; Howe, E. G.; Wheeler, G. A variant Oddy test procedure for evaluating materials used in storage and display cases. Stud. Conserv. 1999, 44, 86-90.

10. Robinet, L.; Thickett, D. A new methodology for accelerated corrosion testing. Stud. Conserv. 2003, 48, 263-268.

11. Hodgkins, R. E.; Centeno, S. A.; Bamberger, J. A.; Tsukada, M.; Schrott, A.; Silver nanofilm sensors for assessing daguerreotype housing materials in an Oddy test setup. e-Preservation Science 2013, 10, 71-76.

12. Thickett, D.; Lee, L. R. Selection of materials for the storage or display of museum objects. The British Museum Occasional Paper 2004, (111). 